Információközvetítés és közösségépítés - multifunkciós könyvtári hálózatok.

Szerk. Kiszl Péter, Németh Katalin. Budapest, ELTE BTK

Könyvtár- és Információtudományi Intézet. 2020. 115-134.

\title{
JOGSZABÁLY GENERÁLTA VÁLTOZÁSOK \\ A MEGYEI KÖNYVTÁRAK TEVÉKENYSÉGÉNEK ALAKULÁSÁBAN
}

2012-2017

\section{FEHÉR MiKLós}

\section{TARTALMI ÖSSZEFOGLALÓ}

A könyvtári rendszer müködése nem képzelhető el szabályozók nélkül. Számos formában és módon próbáljuk elérni azt, hogy az egyes kérdésekben a rendszert alkotó intézmények egységesen, szabályozottan járjanak el. Ugyanakkor érezhető, hogy a fenntartói elvárások, melyek a könyvtárak életében meghatározóak, továbbá az egyéb intézményi törekvések gyakran az egységes szemlélet és eljárásrend ellen hatnak. A tanulmány egy konkrét jogszabály (1997. évi CXL. törvény) és egy konkrét könyvtári kör (megyei könyvtárak) esetében vizsgálja a szabályozó hatását a rendszer müködésére.

A tapasztalatokból a szerző arra a megállapításra jut, hogy a hatékony ellátás érdekében a jogszabályokat módszertannal is támogatni kell, a szakmai döntéseknek pedig a könyvtárak által vezetett együttmüködési körökben javasolt megszületniük. A könyvtári rendszer gyakorlati működését a szubszidiaritás elvét is betartva a könyvtáraknak célszerű moderálniuk. Az ágazati irányítás mérhetetlenül fontos szerepe e szint felett, a kulcsintézményi képességek magas szinten tartásában fogalmazható meg.

\section{Bevezetés, egyben a tanulmány céljának meghatározása}

2010-től meglehetősen sok könyvtári jogszabály jelent meg. Ez folyamatos változást, átalakulást, igazodást követel meg a könyvtáraktól.

- Az 1997. évi CXL. törvény ${ }^{1}$ ebben az időszakban többször, lényeges elemeiben is (pl. a könyvtárak feladatai) változott.

- Ebben az időszakban négy új, a könyvtárak müködését befolyásoló kormányrendelet született.

- Ebben az időszakban tíz új, a könyvtárak müködését befolyásoló miniszteri rendelet jelent meg. ${ }^{2}$

A könyvtárosoknak az új jogszabályok ellenére is az az érzésük, hogy még mindig nagyon sok a szabályozatlan terület. Hiszen továbbra sem tudjuk megmondani, mekkora legyen konkrét esetben egy települési könyvtár, vagy mit kell (csak egyetlen példát kiragadva) azon érteni, hogy az országos szakkönyvtár szakterületére vonatkozóan vesz részt a nemzetiségek könyvtári ellátásának segítésében ${ }^{3}$. Summázhatjuk, a szabályozottság és a szabá- 


\section{FEHÉr MiKLÓs}

lyozatlanság a hazai könyvtári rendszerben együttesen van jelen. A problémát az okozza, ha van is jogszabály, ez önmagában nem garancia az egységesen szabályozott működésre.

Ebből a tényből eljuthatunk arra a következtetésre, hogy a továbblépés érdekében érdemes, sőt szükséges lenne a hazai könyvtári rendszer müködésének átfogó újragondolása. Úgy tűnik, hogy a fejlesztéshez a fenntartó, az állam és a megyei könyvtárak alapvető szerepeinek megtartása mellett kevésbé újabb szabályozókra, inkább az egységes eljárást irányító, menedzselö, támogató, a szabályhasználatot követő és ellenőrző felelősökre és kapacitásokra lenne szükség.

Jelen dolgozatban óhatatlanul érintem a könyvtári rendszer müködését, adott esetben utalást is teszek a tapasztalható nehézségekre, azonban a rendszer átfogó értékelését természetesen nem tüzhettem ki célul. A dolgozatban a jogi eszközök és ezen belül kifejezetten az 1997. évi CXL. tv. érvényesülését, hatását szeretném konkrét környezetben, a megyei könyvtárakra vonatkozó szabályozás fejlődése alapján vizsgálni. Annak áttekintésére vállalkozom, hogy a könyvtári törvény a megyei hatókörű városi könyvtárak működése szempontjából öt év viszonylatában milyen változásokon ment át.

Ezért megvizsgálom az 1997. évi CXL. törvény 2012. január 1-jén és 2017. január 1-jén hatályos szövegét. Továbbá megvizsgálom, hogy a megyei könyvtári beszámolókban vajon kimutatható-e a bekövetkezett törvényi változásokra történő reagálás. Azaz, a jogszabályi változások miatt hogyan, miképpen módosítja tevékenységét a megyei könyvtár, és erről hogyan számol be. Ennek érdekében áttekintem a 2017. évről szóló beszámolókat és elemzem a könyvtári törvény változásának a megyei könyvtárak életére gyakorolt hatását, illetve ennek visszatükröződését az említett dokumentumokban.

\section{1. táblázat}

Az 1997. évi CXL. törvény megyei hatókörü városi könyvtári müködést befolyásoló változásai a jogszabály 2012. január 1-jén és 2017. január 1-jén hatályos szövege alapján

\begin{tabular}{|c|c|}
\hline $\begin{array}{l}\text { A jogszabály } \\
\text { 2012. január 1-jén } \\
\text { hatályos szövege }\end{array}$ & $\begin{array}{c}\text { A jogszabály 2017. január 1-jén } \\
\text { hatályos szövege }\end{array}$ \\
\hline $\begin{array}{l}\text { 1. } \$ \text { E törvény célja: } \\
\text { a) rendelkezni a nemzeti és } \\
\text { az egyetemes történelem so- } \\
\text { rán felhalmozott és megörzött } \\
\text { kulturális javak védelméről, } \\
\text { tudományos feldolgozásáról } \\
\text { és közkinccsé tételéről }\end{array}$ & $\begin{array}{l}\text { 1. } \$ \text { E törvény célja: } \\
\text { a) a társadalmi jólét és a fenntartható fejlődés biztosítása, } \\
\text { az egész életen át tartó tanulás elősegítése, az életminőség } \\
\text { javítása, valamint a kulturális örökség helyi és országos vé- } \\
\text { delme érdekében rendelkezni a kulturális javak gyarapítá- } \\
\text { sának, megőrzésének, tudományos feldolgozásának, a jövő } \\
\text { nemzedékek számára történő átörökítésének és társadalmi } \\
\text { hasznosításának általános szabályairól }\end{array}$ \\
\hline
\end{tabular}

Mint látható, a jogszabály általi feladatmeghatározás bővült, a célt pontosabban írja körül. A különbségre utaló kulcskifejezések: 
- társadalmi jólét,

- fenntartható fejlődés,

- egész életen át tartó tanulás,

- életminőség javítás.

\section{2. táblázat}

Az 1997. évi CXL. törvény megyei hatókörü városi könyvtári müködést befolyásoló változásai a jogszabály 2012. január 1-jén és 2017. január 1-jén hatályos szövege alapján

\begin{tabular}{|c|c|}
\hline $\begin{array}{c}\text { A jogszabály 2012. január 1-jén } \\
\text { hatályos szövege }\end{array}$ & A jogszabály 2017. január 1-jén hatályos szövege \\
\hline $\begin{array}{l}\text { A nyilvános könyvtár alapfel- } \\
\text { adatait felsoroló 55. paragrafus } \\
\text { a) - e) pontokból áll. }\end{array}$ & $\begin{array}{l}\text { A nyilvános könyvtár alapfeladatait felsoroló 55. paragra- } \\
\text { fus a) - e) pontjai kiegészülnek f)-k), valamint (1a) pon- } \\
\text { tokkal az alábbiak szerint: } \\
\text { f) biztosítja az elektronikus könyvtári dokumentumok } \\
\text { elérhetőségét, } \\
\text { g) a könyvtárhasználókat segíti a digitális írástudás, az } \\
\text { információs műveltség elsajátításában, az egész életen át } \\
\text { tartó tanulás folyamatában, } \\
\text { h) segíti az oktatásban, képzésben részt vevők informá- } \\
\text { cióellátását, a tudományos kutatás és az adatbázisokból } \\
\text { történő információkérés lehetőségét, } \\
\text { i) kulturális, közösségi és egyéb könyvtári programokat } \\
\text { szervez, } \\
\text { j) tudás-, információ- és kultúraközvetítő tevékenységével } \\
\text { hozzájárul az életminőség javításához, az ország verseny- } \\
\text { képességének növeléséhez, } \\
\text { k) a szolgáltatásait a könyvtári minőségirányítás szem- } \\
\text { pontjait figyelembe véve szervezi. } \\
\text { (la) A nyilvános könyvtár az általa üzemeltetett, kisko- } \\
\text { rúak által is használható, internet-hozzáféréssel rendel- } \\
\text { kezó számítógépek használatát a kiskorúak védelmét le- } \\
\text { hetővé tevő, könnyen telepíthető és használható, magyar } \\
\text { nyelvű szoftverrel ellátva biztosítja a kiskorúak lelki, testi } \\
\text { és értelmi fejlődésének védelme érdekében. }\end{array}$ \\
\hline
\end{tabular}

Mint látható, a jogszabály általi feladatmeghatározás bővült. A különbségre utaló kulcskifejezések:

- elektronikus könyvtári dokumentumok elérése,

- könyvtárhasználók segítése,

- könyvtári programok (kulturális, közösségi),

- versenyképesség, 


\section{FEHÉr MikLós}

- minőségirányítás a szolgáltatás szervezésben,

- kiskorúak védelme.

\section{3. táblázat}

Az 1997. évi CXL. törvény megyei hatókörü városi könyvtári müködést befolyásoló változásai a jogszabály 2012. január 1-jén és 2017. január 1-jén hatályos szövege alapján

\begin{tabular}{|l|c|}
\hline \multicolumn{1}{|c|}{$\begin{array}{c}\text { A jogszabály 2012. január 1-jén } \\
\text { hatályos szövege }\end{array}$} & \multicolumn{1}{|c|}{$\begin{array}{c}\text { A jogszabály 2017. január 1-jén } \\
\text { hatályos szövege }\end{array}$} \\
\hline $\begin{array}{l}\text { 64. \$. A települési könyvtári ellátás } \\
\text { nyilvános könyvtár szolgáltatásának } \\
\text { megrendelésével teljesíthető }\end{array}$ & $\begin{array}{l}\text { 64. \$. A települési könyvtári ellátás a megyei könyvtár } \\
\text { szolgáltatásainak igénybevételével teljesíthetö, ehhez } \\
\text { megállapodást kell kötni a megyei könyvtárral. }\end{array}$ \\
\hline
\end{tabular}

Mint látható, a jogszabály általi feladatmeghatározás bővült. A különbségre utaló kulcskifejezés:

- megállapodás (kistelepülési önkormányzattal).

\section{4. táblázat}

Az 1997. évi CXL. törvény megyei hatókörü városi könyvtári müködést befolyásoló változásai a jogszabály 2012. január 1-jén és 2017. január 1-jén hatályos szövege alapján

\begin{tabular}{|l|l|}
\hline $\begin{array}{c}\text { A jogszabály 2012. január 1-jén } \\
\text { hatályos szövege }\end{array}$ & \multicolumn{1}{|c|}{$\begin{array}{c}\text { A jogszabály 2017. január 1-jén } \\
\text { hatályos szövege }\end{array}$} \\
\hline $\begin{array}{l}\text { 66. \$. a megyei könyvtár feladatait } \\
\text { sorolja, de ezek között nincs még } \\
\text { ott a Könyvtárellátási Szolgáltató } \\
\text { Rendszer (KSZR) müködtetése. }\end{array}$ & $\begin{array}{l}\text { 66. \$. g) Müködteti a Könyvtárellátási Szolgáltató Rend- } \\
\text { szert paragrafus további i) - m) pontokkal egészül ki az } \\
\text { alábbiak szerint: } \\
\text { i) koordinálja a települési könyvtárak fejlesztését, ennek ke- } \\
\text { retében javaslatot tesz a megyében múködő városi könyv- } \\
\text { tárak és a települési nyilvános könyvtárak fenntartóinak a } \\
\text { könyvtár fejlesztésére a miniszter rendeletében meghatáro- } \\
\text { zott szakmai követelmények érvényesítése érdekében, } \\
\text { j) koordinálja a települési könyvtárak minősítésének elö- } \\
\text { készítését, } \\
\text { k) ellátja az Országos Dokumentum-ellátási Rendszerről } \\
\text { szóló kormányrendeletben a szolgáltató könyvtár szá- } \\
\text { mára meghatározott feladatokat, } \\
\text { l) évente egy alkalommal a könyvtári szolgáltatások } \\
\text { megvalósításával kapcsolatos információs szakmai mü- } \\
\text { helynapot szervez a megye könyvtárosai számára, } \\
\text { m) ellátja a helyismereti dokumentumok elektronikus } \\
\text { hozzáférhetővé tételével kapcsolatos feladatokat. }\end{array}$ \\
\hline
\end{tabular}


Mint látható, a jogszabály általi feladatmeghatározás jelentősen bővült. A különbségre utaló kulcskifejezések:

- KSZR müködtetés,

- koordináció (települési könyvtárak fejlesztése),

- javaslat (települési könyvtárak fejlesztése),

- koordináció (települési könyvtár minősítésének előkészítése),

- ODR szolgáltató könyvtári feladatok ellátása,

- szakmai műhelynap,

- elektronikus hozzáférhetővé tétel (helyismereti dokumentumok).

A megyei hatókörü városi könyvtárak 2017. évröl, illetve kontrollként a 2012. évröl szóló beszámolóinak vizsgálata

(Annak áttekintése, hogy az 1997. évi CXL. törvény időközbeni módosulásai a könyvtár működési gyakorlatára voltak-e, s milyen hatással, s ez a beszámolóban hogyan tükröződik)

A vizsgálat sorrendje:

1. A tanulmány második részében rögzített kulcskifejezéseket betürendbe soroltam.

- egész életen át tartó tanulás

- elektronikus hozzáférhetővé tétel (helyismereti dokumentumok)

- elektronikus könyvtári dokumentumok elérése

- életminőség javítás

- fenntartható fejlődés

- javaslat/koordináció (települési könyvtárak fejlesztése)

- kiskorúak védelme

- koordináció (települési könyvtár minősítésének előkészítése)

- könyvtárhasználók segítése

- könyvtári programok (kulturális, közösségi)

- KSZR müködtetés

- megállapodás (kistelepülési önkormányzattal)

- minőségirányítás a szolgáltatás szervezésben

- ODR szolgáltató könyvtári feladatok ellátása

- szakmai műhelynap

- társadalmi jólét

- versenyképesség

2. Megszámoltam a kulcskifejezések beszámolókban történő megjelenési gyakoriságát. A megjelenéseket négy kategóriába soroltam. Releváns, lényegi említésnek azt tekintettem, amely esetben a kulcskifejezés szövegkörnyezete a tárgyhoz kapcsolódó, adatokkal is alátámasztott információt is tartalmazott. 


\section{FEHÉr MiKLÓs}

3. Megjegyzéseket, kiegészítéseket füztem az egyes találatokhoz.

4. Mindezt táblázatba helyeztem, a könnyebb áttekinthetőség kedvéért.

A vizsgálat kapcsán megjegyzendö, hogy összesen 10 megyei hatókörü városi könyvtár 14 beszámolóját ( $8 \mathrm{db}$ beszámoló 2017-ről és $6 \mathrm{db}$ beszámoló 2012-ről) vettem a fentiek szerint górcső alá. ${ }^{4}$

Táblázatok a 2017-es beszámolók alapján

2.1. táblázat

Az 1997. évi CXL. törvény hatása a beszámolók alapján

\begin{tabular}{|c|c|c|c|}
\hline $\begin{array}{l}\text { Sor- } \\
\text { szám }\end{array}$ & Kulcskifejezés & Megjegyzés & Érték \\
\hline 1. & $\begin{array}{l}\text { egész életen át } \\
\text { tartó tanulás }\end{array}$ & $\begin{array}{l}\text { - Nincs említés a beszámolóban } \\
\text { - Irreleváns említés található a beszámolóban } \\
\text { - Releváns, de nem lényegi említés van a beszámoló- } \\
\text { ban } \\
\text { - Releváns lényegi említés van a beszámolóban }\end{array}$ & $\begin{array}{l}2 \\
5 \\
2 \\
0\end{array}$ \\
\hline
\end{tabular}

Úgy tünik, hogy az „egész életen át tartó tanulás”, mint elvárás 2017-es megjelenése a könyvtárak müködési gyakorlatát alapjaiban nem változtatta meg. Az ezzel kapcsolatos említések a beszámolókban inkább csak rögzítik a tényt, hogy ezt fontosnak tartja a könyvtár. Egy beszámoló átlagosan 0,875 alkalommal jeleníti meg a kifejezést, de irreleváns tartalmakkal, például: fontosnak tartjuk az egész életen át tartó tanulás támogatását. De előfordul, hogy egy pályázat kapcsán, annak témájaként utal a beszámoló az egész életen át tartó tanulás témakörére.

$\mathrm{Az}$ „egész életen át tartó tanulás”, illetve ennek támogatása az 1-es paragrafusban, a törvény céljai közt kerül felsorolásra 2017-ben. Azt rögzíthetjük, hogy ebben az esetben a törvény a gyakorlatot követte, azaz az elvárás joganyagba emelése egy meglévő gyakorlat szentesítését jelentette. Erre utal az a tény, hogy a 2012-es beszámolókat áttekintve azt tapasztalhatjuk, hogy a könyvtárak már akkor is adtak jelentést erről a tevékenységi körről. Sőt ez a számot adás szinte azonos értékű a 2017-es jelentéshez képest, hiszen 2012-ben 0,667, míg 2017-ben 0,875 alkalommal jelenik meg a beszámolókban a kifejezés. Ez nem releváns különbség. Azaz kimondható, hogy ebben az esetben a törvényi megerősítésnek érdemi hatása az „egész életen át tartó tanulás" könyvtári támogatására nem volt. 
JogSZABÁLY GENERÁLTA VÁLTOZÁSOK A MEGYEI KÖNYVTÁRAK...

2.2. táblázat

Az 1997. évi CXL. törvény hatása a beszámolók alapján

\begin{tabular}{|l|l|l|r|}
\hline 2. & elektronikus hozzáfér- & - Nincs említés a beszámolóban & 1 \\
hetővé tétel (helyisme- & - Irreleváns említés található a beszámolóban & 130 \\
reti dokumentumok) & - Releváns, de nem lényegi említés van a beszámolóban & 28 \\
- Releváns lényegi említés van a beszámolóban & 8 \\
\hline
\end{tabular}

A helyismereti tevékenység és a helyismereti gyüjtőmunka eredményeinek elektronikus hozzáférhetővé tétele a települési könyvtárak életében hagyományosan kiemelkedően fontos tevékenységnek számít. Az említési számok ezt a fontosságot alátámasztják. Egy beszámoló átlagosan 20,125 alkalommal jeleníti meg a kifejezést. Igaz, az emlitések legtöbb esetben irreleváns vagy releváns, de kiegészítő és egyedi tevékenységet bemutató információ nélküli tartalmat takarnak. Utóbbira példa az, amikor a beszámoló felsorolja a könyvtár törvényben rögzitett alapfeladatait, köztük ezt a pontot is (ellátja a helyismereti dokumentumok elektronikus hozzáférhetővé tételével kapcsolatos feladatokat), de nem füz hozzá semmiféle többlet információt arról, hogy ennek keretében a könyvtár mit is tett.

A feladat a 66. \$-ban jelenik meg, ami a megyei könyvtár a megye egész területére vonatkozó feladatait sorolja fel. Ez a pont a kötelezően ellátandó alapfeladatok körét jelöli ki. Ennek megfelelően az egyik beszámoló ki is emeli ezt a területet és külön pontban foglalkozik a tárgyban végzett tevékenységével. A többi vizsgált dokumentumban azonban ez a „kiemelés” nincs jelen, sőt van egy beszámoló, amelyik ezt a területet egyáltalán nem is említi.

Ha a 2012-es beszámolókhoz hasonlítjuk az értékeket, akkor azt láthatjuk, hogy akkor az egy könyvtárra eső említések száma 16,167 volt, és ez az érték emelkedett 2017-ben 20,125 re. Ez már egy érzékelhető emelkedés, figyelembe kell azonban venni, hogy a 2012-ben elért említési szám kiemelkedően a legmagasabb volt az öszszes vizsgált szempont közül. 2017-re a megemelkedett említési szám azonban csak a harmadik helyhez lett elegendő. Ez arra utal, hogy a helyismereti tevékenység a prioritás sorban hátrább került, hiába kapott jogszabályi megerősítést.

\section{3. táblázat}

Az 1997. évi CXL. törvény hatása a beszámolók alapján

\begin{tabular}{|l|l|l|r|}
\hline \multirow{3}{*}{ 3. } & elektronikus könyv- & - Nincs említés a beszámolóban & 3 \\
& tári dokumentumok & - Irreleváns említés található a beszámolóban & 15 \\
& - Releváns, de nem lényegi említés van a beszámolóban & 3 \\
\hline
\end{tabular}

Az elektronikus könyvtári dokumentumok elérését támogató tevékenység a nyilvános könyvtár alapfeladatait felsoroló 55. paragrafusban került meghatározásra. Az addigi öt alapfeladat egészült ki már 2013-tól ezzel. Ennek ellenére 2017-ben az tapasztalhatjuk, 


\section{FEHÉr MiKLÓs}

hogy a beszámolók még meglehetősen kevés számban foglalkoznak a feladattal. Az egy beszámolóra eső említések száma mindösszesen 2,75. Releváns említés a beszámolók felében lelhető fel, ami a kötelező feladat elöíráshoz viszonyítva nem tűnik elégséges értéknek. Ha ennek okait keressük, amiböl számos lehet, említenünk kell azt, hogy vannak feladatok, amik „egy mondattal is elintézhetőek” a beszámolóban és vannak, amikről hosszasabban, részletesebben kell szólni. Lehetséges, hogy ez is az egyszerűbben beszámolható feladatok közé tartozik. De van egy másik lehetséges magyarázat is, ami szerint a feladat tartalma nem egységesen értelmezett. A „helyismereti munkán” mindenki tudja, mit kell érteni, ugyanez az egységes értelmezés az „elektronikus könyvtári dokumentumok elérhetőségét támogató tevékenység” kapcsán még nem alakult ki. Mi az az indikátor, aminek a megléte vagy elérése esetén a tevékenység elvégzettnek minősíthető? Úgy tünik, ha érdemi változást szeretnénk elérni, akkor a jogszabályok önmagukban nem elégségesek, tartozniuk kell hozzájuk végrehajtási módszertani támogatásnak is.

További furcsaság, ami nemcsak ennél a pontnál fordul elő, de először itt tapasztalhatjuk, hogy a 2012-es említési gyakoriság - 3,167 - magasabb(!) a 2017-es 2,75-ös értékhez képest. Úgy tünik, hiába került be az alapfeladatok közé ez a terület, a könyvtárak működésük során az ezzel kapcsolatos feladatellátást vagy háttérbe szorították vagy el sem végezték. Ha ennek okait keressük, akkor szembesíteni kell magunkat azzal a ténnyel, hogy a megyei könyvtárak a belépő új feladatok ellátására a vizsgált időszakban nem kaptak többlet müködési támogatást. Azaz vagy saját kapacitásuk hatékonyabb kihasználásával tudhatták elérni az új belépő feladat ellátást vagy rákényszerültek arra, hogy a feladataik egy részét más arányban végezzék el. Ebben az esetben vannak „nyertes” feladatok, de kell, hogy legyenek „vesztesek” is.

\section{4. táblázat}

Az 1997. évi CXL. törvény hatása a beszámolók alapján

\begin{tabular}{|l|l|l|l|}
\hline \multirow{4}{*}{ 4. } & \multirow{2}{*}{ életminőség javítás } & $\begin{array}{l}\text { - Nincs említés a beszámolóban } \\
\text { - Irreleváns említés található a beszámolóban } \\
\text { - Releváns, de nem lényegi említés van a beszámolóban } \\
\text { - Releváns lényegi említés van a beszámolóban }\end{array}$ & 5 \\
& & 3 \\
\hline
\end{tabular}

Úgy tűnik, a vesztesek közé tartozik az „életminőség javítás”, illetve az ezzel kapcsolatos tevékenységek beszámolókban történő láttatása is. Az egy beszámolóra eső említések száma mindösszesen 0,5. Ténylegesen bizonyítékokon alapuló információk ebből a néhány említésben sem derülnek ki, megtudjuk, hogy „figyelmet kapnak az életminőséget javitó képzések", de hogy melyek ezek és milyen kimutatható eredmény született, arra már nincs utalás. Ez a feladat is a törvény céljának meghatározásából származtatható, azaz nem szakmai feladatellátás, hanem társadalompolitikai elvárás húzódik meg mögötte. Ezzel együtt fontos lenne tisztázni, mit értsünk az „életminőség javításon", és mi számít eredménynek. 
Hogy valami mégis elmozdult, arra az utal, hogy 2012-ben ez a tevékenység 0,0 említést kapott, tehát egyáltalán nem volt rá utalás. Ehhez képest a néhány említés mindenképpen előrelépésnek számít. Ezzel együtt az látszik, hogy erre a feladatkörre, illetve a kapcsolódó kommunikációra a könyvtárak nem tudnak erőforrást biztosítani.

\section{5. táblázat}

Az 1997. évi CXL. törvény hatása a beszámolók alapján

\begin{tabular}{|l|l|l|l|}
\hline \multirow{5}{*}{ 5. fenntartható fejlődés } & $\begin{array}{l}\text { - Nincs említés a beszámolóban } \\
\text { - Irreleváns említés található a beszámolóban }\end{array}$ & 7 \\
& & - Releváns, de nem lényegi említés van a beszámolóban & 1 \\
& - Releváns lényegi említés van a beszámolóban & 0 \\
\hline
\end{tabular}

A „fenntartható fejlődés” kapcsán szinte ugyanazok a megállapítások tehetők meg, mint amiket az előző pontban az „életminőség javítás” kapcsán tettünk. Ez a feladat is a törvény céljának meghatározásából származtatható, azaz itt sem a szakmai feladatellátást, hanem a társadalompolitikai cél teljesítésének szükségességét, mint elvárást érzékelhetjük. Munkánkat rendkívül nehéz úgy szervezni, hogy a feladatellátás apró részleteit, illetve komplexebb folyamatait minden esetben megfeleltessük a fenntartható fejlődés elvárásrendszerének. Ehhez átfogó és tudatosult szemléletmódra lenne szükség nemcsak a vezetők részéről, de valamennyi munkatárs esetében is. Ha ezt a megállapítást elfogadjuk, akkor ezzel azt is kijelentjük, hogy ezen a területen képzésre, képzésre és képzésre lenne szükség. A képzés és a jó gyakorlatok terjesztése és átültetése (módszertani támogatás) lehet a kizárólagos útja a hatékony és gyors elörelépésnek, a felmutatható eredmények megszületésének.

2017-ben az egy beszámolóra eső említések száma mindösszesen 0,125 volt, ami majdnem a „0”-val egyenértékű. 2012-ben meglepő módon 0,333-as érték képződött, azaz egyfelöl az látszik, hogy a törvényi megfogalmazás nélkül is foglalkoztak a könyvtárak a fenntarthatóság kérdéskörével, másrészt az is egyértelmü, hogy ezen a területen komolyabb eredmények, előrelépések még nem történtek.

\section{6. táblázat}

Az 1997. évi CXL. törvény hatása a beszámolók alapján

\begin{tabular}{|l|l|l|r|}
\hline 6. & javaslat/koordináció & - Nincs említés a beszámolóban & 1 \\
& (települési könyvtá- & - Irreleváns említés található a beszámolóban & 4 \\
rak fejlesztése) & - Releváns, de nem lényegi említés van a beszámolóban & 4 \\
& - Releváns lényegi említés van a beszámolóban & 1 \\
\hline
\end{tabular}

A 2017-es beszámolók többsége szól a kistelepülési könyvtári ellátás szervezéséről, de ez az említés sajnos nem a fejlesztési stratégia szemszögéből történik. Valójában az sem derül ki, hogy létezik-e ilyen dokumentum. A feladat a Tv. 66. \$-ában jelenik meg, ami 


\section{FEHÉr MiKLÓs}

a megyei könyvtár a megye egész területére vonatkozó feladatait sorolja fel. Ez a pont a kötelezően ellátandó alapfeladatok körét jelöli ki. A feladat súlyához képest az egy könyvtárra eső említések száma mindösszesen 1,125-ös értéket mutat, tehát a könyvtárak „egy lépésben” elintézik ezt a kérdést utalva például arra, hogy „a fejlesztés érdekében lakossági vizsgálatot tartottak”. Itt természetesen kell szólnunk arról a tényről, hogy a megyei könyvtárak KSZR beszámoló megtételére is kötelezettek, azaz lehetséges, hogy az ezzel kapcsolatos információk ott vannak elhelyezve. Mivel ez nem volt a vizsgálatom tárgya, így ennek hiányában ebben a vonatkozásban további értékelő megállapítást nem teszek. Mindenesetre ezen lehetséges magyarázatot alátámasztani látszik az a tény, hogy 2012-ben, a beszámolókban, az egy könyvtárra eső említések száma még jóval magasabb, 3,167 értéket mutatott.

\section{7. táblázat}

Az 1997. évi CXL. törvény hatása a beszámolók alapján

\begin{tabular}{|l|l|l|l|}
\hline \multirow{3}{*}{ 7. } & \multirow{2}{*}{ kiskorúak védelme } & $\begin{array}{l}\text { - Nincs említés a beszámolóban } \\
\text { - Irreleváns említés található a beszámolóban } \\
\text { - Releváns, de nem lényegi említés van a beszámolóban } \\
\end{array}$ & 0 \\
& - Releváns lényegi említés van a beszámolóban & 0 \\
& & 0 \\
\hline
\end{tabular}

A kiskorúak védelme az 55. \$-ban, az alapfeladatok felsorolásánál meglehetősen részletesen és egyértelműen van kifejtve. „A nyilvános könyvtár az általa üzemeltetett, kiskorúak által is használható, internet-hozzáféréssel rendelkező számítógépek használatát a kiskorúak védelmét lehetövé tevő, könnyen telepithető és használható, magyar nyelvü szoftverrel ellátva biztosítja a kiskorúak lelki, testi és értelmi fejlödésének védelme érdekében". A beszámoló ebben az esetben tényleg rövid tényközléssel megoldható, van-e szoftveres védelem mindazokon az eszközökön, amelyekről kiskorú internet hozzáférést érhet el. Úgy tünik azonban, hogy ezzel a kérdéssel a könyvtárak egészen egyszerüen elfelejtkeztek foglalkozni, pontosabban, ha foglalkoztak vele - és feltételezhető, hogy igen - a róla szóló beszámolás maradt el. Az egy könyvtárra eső említések száma 2017-ben nulla értéket mutat. Ugyanennyi a 2012-es érték is. A szabályozás egyébként 2014. szeptember 1-jén lépett hatályba, azaz 2017-ben már nem lehetett ismeretlen a könyvtárak számára.

\section{8. táblázat}

Az 1997. évi CXL. törvény hatása a beszámolók alapján

\begin{tabular}{|l|l|l|l|}
\hline 8. & koordináció (te- & - Nincs említés a beszámolóban & 0 \\
& lepülési könyvtár & - Irreleváns említés található a beszámolóban & 0 \\
& minősítésének elö- & - Releváns, de nem lényegi említés van a beszámolóban & 0 \\
& készítése) & - Releváns lényegi említés van a beszámolóban & 8 \\
\hline
\end{tabular}


A feladat a 66 . $\$$-ban jelenik meg, ami a megyei könyvtárnak a megye egész területére vonatkozó feladatait sorolja fel. A koordinációk számának megadásával egyértelmüen kiderül, hogy a könyvtár végez-e ezzel összefüggésben tevékenységet. A megyei könyvtárak beszámoló sablonjába ${ }^{5}$ ez a kérdés beépült, így a nyolc könyvtárból nyolc releváns és lényegi válasz érkezett. A tevékenység végzéséről tehát kapunk képet, pontos ismeretünk a tevékenység mértékéről azonban ennek ellenére sincsen. Hiszen két könyvtár azt válaszolta, hogy ebben az évben (2017) nem támogatnak senkit sem minősítés előkészítéssel. Volt, aki arról adott számot, hogy ennek érdekében pályázatot nyújtott be (hogy a feladat elvégzéséhez forrást szerezzen saját maga számára) és volt, aki konkrétan megnevezte, hogy 4 vagy 6 vagy több mint 10 könyvtárat is támogatott. Mindezek lényeges különbségek. A könyvtárak ösztönzése és minősítésre történő felkészülésüknek támogatása a könyvtári rendszerben elvileg nem lehet pénzkérdés. Azaz, nem függhet attól a tevékenység ellátása, hogy adott évben sikerül-e erre a célra plusz pályázati forrást találni. Sajnos a gyakorlat viszont azt mutatja, hogy a megyei könyvtáraknak megint csak mérlegelniük kell, hogy a bővülő feladatlista egyes tételeit milyen munkaerő és költségvetés átcsoportosítással tudják ellátni, hiszen a költségvetési támogatás nem bővült olyan mértékben, mint amennyit a feladatellátási kötelezettség teljesítése megkövetelne.

Ennek a feladatnak a teljesítésébe ugyanakkor a Könyvtári Intézet 2018-ban bekapcsolódott és már a minőség pályázatok úgy kerültek kiírásra, hogy a címet, díjat elnyerők vállalják, hogy maguk is involválódnak a minősítéssel kapcsolatos információk terjesztésébe. Azaz, a disszemináció során alkalmazásra került a multi-level marketingből ismert elv, a „vevőből” „eladó” lesz, és újabb vevőket ösztönöz a rendszerbe történő belépésre. Az eredmények igazolják, hogy ez a megoldás - pontosabban a könyvtárak nagy száma miatt kizárólag ez a megoldás - a müködőképes. Emellett alkalmas arra is, hogy a megyei könyvtárakat részlegesen tehermentesítsük az ezzel összefüggő feladataik ellátásában. Ez azt is garantálja, hogy intenzíven, tíz éven belül minden nyilvános könyvtár a gyakorlatban érdemi segítséget és ismereteket kapjon a saját intézménye minősítésének előkészítéséhez. Ha ez bekövetkezik, akkor a könyvtári rendszer egésze újabb lépést tehet a minőség útján és a jelenleg javasolt kritériumrendszer teljesítmény értékei, követelmény szintjei központilag emelhetők lesznek. Mindez garantálja a minőség és az ennek érdekében alkalmazott szervezeti módszerek folyamatos fejlesztését.

A könyvtári minőségügy fejlesztése kapcsán a fentiekben leírt megoldási javaslat mellett érdekes eredményt mutat a 2012-es beszámolók áttekintése is. Míg 2017 ben az egy könyvtárra eső említések száma 1, addig ez az érték 2012-ben már 1,5 volt! Két dolgot kell azonnal hozzáfüznünk, hogy a kapott eredményt megfelelően értelmezhessük. Egyrészt azt, hogy ahogyan már említésre került, 2017-ben minden könyvtár e tárgyban releváns és lényegi elemeket tartalmazó közlést adott a beszámolóban, míg 2012-ben a minőségüggyel kapcsolatos említések az „irreleváns” kate- 


\section{FEHÉr MiKLÓs}

góriában születtek. Tehát ebben az esetben sokkal jobb a kevesebb, de releváns érték a több, de irrelevánsnál. Másrészt az eredmény utal arra, hogy a minőség kérdésével stratégiai szinten már korábban is foglalkozott az ágazat irányítás és a megyei könyvtárak sem az erre vonatkozó törvényi feladat megjelenését követően kezdtek el ezzel a kérdéskörrel dolgozni, hanem ezt már lényegesen korábban megtették. A törvényi szabályozás beléptetésének ezek szerint ebben az esetben a megerősítés és a minőségügyi folyamatok felgyorsítása lehetett a célja, amiben a Könyvtári Intézet lényeges és eredményes lépéseket tudott megtenni.

\section{9. táblázat}

Az 1997. évi CXL. törvény hatása a beszámolók alapján

\begin{tabular}{|l|l|l|r|}
\hline \multirow{3}{*}{ 9. } & \multirow{2}{*}{$\begin{array}{l}\text { könyvtárhasználók } \\
\text { segítése }\end{array}$} & - Nincs említés a beszámolóban & 0 \\
& & - Rreleváns említés található a beszámolóban & 129 \\
& & - Releváns, de nem lényegi említés van a beszámolóban & 25 \\
& & & 10 \\
\hline
\end{tabular}

A helyismereti tevékenység és a helyismereti gyüjtőmunka eredményeinek elektronikus hozzáférhetővé tétele (lásd 2. tábla) mellett, azt kicsivel megelőzve ért el említési értéket a könyvtárhasználók segítése, ami az alapfeladatokat felsoroló 55. \$-ban jelent meg, méghozzá úgy fogalmazva, hogy a könyvtárhasználókat segíti a digitális írástudás, az információs műveltség elsajátításában, az egész életen át tartó tanulás folyamatában. 2017-ben ezzel összefüggésben az egy könyvtárra eső említések száma 20,5 volt. Ha összevetjük ezt az értéket a 2012-es beszámolók alapján mértekkel $(9,5)$, akkor dinamikus emelkedést regisztrálhatunk. Ez alátámasztja a szubjektív érzésünket, tapasztalatainkat is, miszerint a könyvtárak számos és egyre több könyvtárhasználót, illetve könyvtárhasználatot támogató, digitális írás- és olvasásfejlesztő programot szerveznek.

Ugyanakkor az eredmények lassan megteremtik, megteremthetik a lehetőségét annak, hogy a könyvtárhasználók segítését neazonosítsuk a digitáliskompetencia-fejlesztő programokkal, a könyvtárhasználati bemutatókkal. Érdemes lenne továbbgondolni a kérdést, hogy a könyvtárhasználót a könyvtárhasználatban milyen egyéb kezdeményezések, kapcsolatok, közösségek segíthetik, támogathatják. Lehet, hogy nemcsak direkt képzésekkel, hanem közvetett megoldásokkal is eljuthatunk a segítségre szoruló könyvtárhasználóhoz.

\subsection{0. táblázat}

Az 1997. évi CXL. törvény hatása a beszámolók alapján

\begin{tabular}{|l|l|l|r|}
\hline \multirow{4}{*}{ 10. } & könyvtári progra- & - Nincs említés a beszámolóban & 0 \\
& mok (kulturális, & - Irreleváns említés található a beszámolóban & 89 \\
& közösségi) & - Releváns, de nem lényegi említés van a beszámolóban & 10 \\
& & - Releváns lényegi említés van a beszámolóban & 9 \\
\hline
\end{tabular}


A könyvtári programok száma az utóbbi években dinamikusan nő. A megyei könyvtárak nemcsak saját tereikben, hanem a megyei ellátási hálózat színhelyein is számos programot menedzselnek, koordinálnak. A kiemelkedő figyelmet igazolja az említések száma is. Egy beszámoló átlagosan 13,5 alkalommal jeleníti meg a kifejezést és a tárgyban minden könyvtár közöl releváns, lényegi tartalmakat is a beszámolójában.

A könyvtári programok szervezését, megvalósítását előíró tevékenység (kulturális, közösségi és egyéb könyvtári programokat szervez) a nyilvános könyvtár alapfeladatait felsoroló 55. \$-ban került meghatározásra. Az addigi öt alapfeladat egészült ki ezzel az elöirással már 2013-tól, amit azután 2015-ben módosítottak. A 2012-es adatok megvizsgálásából ugyanakkor arra derül fény, hogy a könyvtárak már akkor is hangsúlyosan foglalkoztak ezzel a feladattal. A rendezvények száma valóban kevesebb volt még, de a figyelem mértéke szinte ugyanakkora lehetett, hiszen egy beszámoló átlagosan 11,33 alkalommal jeleníti meg a kifejezést, igaz a beszámolók kevesebb releváns, lényegi említést tartalmaztak. Összességében ennél a pontnál is azt mondhatjuk, hogy az elöírás jogszabályban való megjelenése nem indukált változást a könyvtárak müködésében.

\subsection{1. táblázat}

Az 1997. évi CXL. törvény hatása a beszámolók alapján

\begin{tabular}{|l|l|l|r|}
\hline \multirow{3}{*}{ 11. } & \multirow{2}{*}{ KSZR működtetés } & - Nincs említés a beszámolóban & 0 \\
& & - Irreleváns említés található a beszámolóban & 164 \\
& & - Releváns, de nem lényegi említés van a beszámolóban \\
& & - Releváns lényegi említés van a beszámolóban & 95 \\
\hline
\end{tabular}

A KSZR kifejezést egy beszámoló átlagosan 34,375 alkalommal említi meg. Ez az érték messze „kilóg” felfelé a sorból, hiszen az őt követő említés szám csupán 20,5 (könyvtárhasználók segítése). Mindez arra utal, hogy a megyei könyvtárak működésébe a KSZR nemcsak beépült, hanem az egész tevékenységüket áthatóvá és lényegében azt meghatározóvá vált. Minden vagy a legtöbb minden a KSZR által determinált környezetben és erőforrások mentén születik meg. A gondolkodás is átalakult. Bármilyen fejlesztés, elörelépés, rendezvény kapcsán felmerül az, hogy mindez hogyan hasznosítható a KSZR számára. A KSZR tevékenységről egyébként a megyei könyvtárak külön, célzott beszámolót is készítenek. Ennek relációjában azt gondolhatnánk, hogy az intézményi beszámolóban a KSZR már nem foglal majd el olyan domináns helyet, hiszen a KSZR-ről történő beszámolásnak külön fóruma van. De, mint látható, nem ez történik. A most vizsgált és jelentősnek gondolt, összesen 17 szempontból a KSZR tevékenységi információk kiemelkedően a leghangsúlyosabbak.

Összevetve a 2012-es adatokat azt látjuk, hogy óriási a változás. 2012-ben még a 7. fontossági (említési gyakorisági) helyen végzett a települési ellátás témaköre az akkori 2,33-as említési értékkel. Tehát hat terület a most vizsgáltak közül megelőzte őt. Felmerül a kérdés, hogy vajon ez az eredmény pusztán a törvényben történő dek- 


\section{FEHÉr MiKLÓs}

larációnak köszönhetö-e? A feladat a 66. \$-ban jelenik meg, ami a megyei könyvtár a megye egész területére vonatkozó feladatait sorolja fel. Ez a pont a kötelezően ellátandó alapfeladatok körét jelöli ki. Míg más, ugyanezen a törvényi helyen megjelenő új feladatnál nem érzékelhető, vagy csak kismértékben érzékelhető változás, addig a KSZR működtetés egészen más pályát futott be.

Természetesen mindennek megvan a magyarázata. Egyrészt a KSZR tevékenység anyagi támogatása célzott és jelentős összegü. Ilyen támogatást az egyéb feladatok már nem élveznek. Másrészt a tevékenység ellátásával összefüggésben a megyei könyvtárak a minisztérium vezetésével KSZR műhelynap sorozatot működtettek ebben az időszakban. Ezeken a mühelynapokon részletesen elemezték a visszamért eredményeket. Közös gondolkodással az eljárásokat egyre finomították. A tevékenység elemek egységesítésre kerültek és személyes tapasztalással lehetett megismerni a legjobb gyakorlatokat. A tevékenység pénzügyi és módszertani támogatást is élvezett. Szó sincs tehát arról, hogy önmagában a törvényben történő megjelenés érte volna el ezt a hatást. Mindez megerősíthet bennünket abban, hogy a rendszer változtatása, dinamikus alakítása egyrészt lehetséges, másrészt viszont abban is, hogy ehhez a jogszabályi környezet hozzáigazításán kívül anyagi forrásokra és aktív, folyamatos módszertani támogatásra egyaránt szükség van.

\subsection{2. táblázat}

Az 1997. évi CXL. törvény hatása a beszámolók alapján

\begin{tabular}{|l|l|l|r|}
\hline 12. & megállapodás (kis- & - Nincs említés a beszámolóban & 0 \\
& települési önkor- & - Irreleváns említés található a beszámolóban & 27 \\
mányzattal) & - Releváns, de nem lényegi említés van a beszámolóban & 8 \\
& - Releváns lényegi említés van a beszámolóban & 9 \\
\hline
\end{tabular}

A feladat a 64. \$-ban jelenik meg. A megállapodások említési számának megadásával egyértelmüen kiderül, hogy ezzel összefüggésben minden könyvtár végez tevékenységet. A megyei könyvtárak beszámoló sablonjába ez a kérdés beépült, így természetesnek mondhatjuk, hogy minden könyvtár beszámolójában van releváns és lényegi válasz erre a pontra. Az egy könyvtárra eső átlagos említések száma 5,5, ami meglehetősen magas érték, a lista 6. helyét jelenti. Összevetve a 2012-es beszámolókban tapasztaltakkal akkor 2,67-es említési gyakoriságot rögzíthettünk, ehhez képest is jelentős az elmozdulás.

\subsection{3. táblázat}

Az 1997. évi CXL. törvény hatása a beszámolók alapján

\begin{tabular}{|l|l|l|r|}
\hline \multirow{4}{*}{ 13. } & minőségirányítás a & - Nincs említés a beszámolóban & 0 \\
& szolgáltatás szerve- & - Irreleváns említés található a beszámolóban & 53 \\
& zésben & - Releváns, de nem lényegi említés van a beszámolóban & 38 \\
& & - Releváns lényegi említés van a beszámolóban & 4 \\
\hline
\end{tabular}


A feladat 2014. január 12-töl hatályos, és a törvény 55. \$-a rendelkezik róla, amelyben a nyilvános könyvtár alapfeladatai vannak felsorolva. A szolgáltatások könyvtári minőségirányítás szempontjait figyelembe vevő szervezése tehát alapfeladattá vált. Ugyanakkor érzékelhető és a számos (38) releváns, de lényegi információt nem tartalmazó említés is erre utal, hogy a könyvtárak még ma sem pontosan értik, tudják, hogy ezen alapfeladatot hogyan is kellene teljesíteniük, ezzel kapcsolatban miről és hogyan kellene beszámolniuk. Ezzel együtt az egy könyvtárra eső említések száma 11,875, ami eléggé magas érték. A minőségi szemlélet és ennek szolgáltatási folyamatokban történő megjelenése tehát fontos az intézmények számára. Ugyanakkor az a széles körű módszertani támogatás, ami megerősíthette volna a célok gyakorlatba történő átültetését, ebben az időszakban elmaradt vagy nem hasznosult megfelelőképpen.

A 2012-es beszámolókat áttekintve akkor az említések száma 0,333 volt. Ez egy lényeges és a minőségügy irányába történő jelentős elmozdulást jelent, amit ebben az időszakban általában is tapasztalhattunk. Lásd a 8. tábla kapcsán írtakat is.

2.14. táblázat

Az 1997. évi CXL törvény hatása a beszámolók alapján

\begin{tabular}{|c|c|c|c|}
\hline 14. & $\begin{array}{l}\text { ODR szolgáltató } \\
\text { könyvtári felada- } \\
\text { tok ellátása }\end{array}$ & $\begin{array}{l}\text { - Nincs említés a beszámolóban } \\
\text { - Irreleváns említés található a beszámolóban } \\
\text { - Releváns, de nem lényegi említés van a beszámolóban } \\
\text { - Releváns lényegi említés van a beszámolóban }\end{array}$ & $\begin{array}{r}0 \\
13 \\
31 \\
6\end{array}$ \\
\hline
\end{tabular}

A feladat a 66. \$-ban jelenik meg, ami a megyei könyvtár a megye egész területére vonatkozó feladatait sorolja fel. Ez a pont a kötelezően ellátandó alapfeladatok körét jelöli ki. A pontos fogalmazás szerint a megyei könyvtár ellátja az Országos Dokumentum-ellátási Rendszerről szóló kormányrendeletben ${ }^{6}$ a szolgáltató könyvtár számára meghatározott feladatokat, amik az alábbiak:

- a gyüjteményében lévő dokumentumok - a szolgáltatásukra vonatkozó előírásokkal együtt történő - bejelentése az országos lelőhely-nyilvántartásba;

- a könyvtárhasználati szabályzatában foglalt korlátozások figyelembevételével - a gyüjteményében lévő dokumentumok teljes körének szolgáltatása. A dokumentum szolgáltatásával egyidejűleg annak használatára, ha kell, egyedi előírások meghatározása;

- az igény haladéktalan teljesítése eredetiben, másolatban, elektronikus vagy egyéb formátumban. Értesítés a kérö könyvtárnak a kérés teljesítésének akadályáról;

- gondoskodás a könyvtárközi dokumentumszolgáltatás korszerủ eszközökkel történő működtetéséről, folyamatosságáról és minőségének biztosításáról, továbbá a szolgáltatás adatainak a minisztérium által előírt nyilvántartásáról. 


\section{FEHÉr MiKLÓs}

A feladatok, mint látható, pontosan és precízen vannak megadva, de ez, ahogyan erre már az előző esetekben is volt utalás nem jelenti automatikusan azt, hogy ebből következően a könyvtárak is pontosan és precízen értik teendőiket és erről a beszámolóban érdemben számot is adnak. A beszámoló struktúrában külön pontba van beépítve az ODR tevékenységről szóló rész. Az önálló pontban általában megjelennek a szolgáltatás mennyiségi adatai, de a mennyiségi eredmények közlése nem azonos a szolgáltató könyvtár feladatai teljesítésének értékelésével. Ebben a vonatkozásban igen hiányosak a beszámolók. Ezért lehetséges, hogy az egy könyvtárra eső átlagos 6,25 említés ellenére mindössze 6 releváns lényegi említés történt. Az említések nagyobb része releváns ugyan, de nem fókuszál a szolgáltató könyvtári feladatokra, amelyekről elmondható, hogy egységes értelmezésük sem egyszerü. Mit is jelent az, hogy gondoskodik a könyvtárközi dokumentumszolgáltatás korszerű eszközökkel történő működtetéséről. Nem tudunk olyan központi listáról, jegyzékröl, ami a könyvtárközi dokumentumszolgáltatás korszerű eszközeit paraméterezné, és lehetővé tenné ennek a kritériumnak egzakt vizsgálatát. De megakadhatunk akkor is, ha a könyvtárközi dokumentumszolgáltatás minőségének biztosításáról, illetve ennek teljesítéséről kellene nyilatkozni.

A 2012-es beszámolókban nem meglepő módon, hiszen az ODR működése sem 2012-ben indult, az említések gyakorisága 5,167 volt, ami alig maradt el a 2017-es beszámolók alapján mért 6,25-ös átlag értéktől. Lényegesebb különbséget mégis felfedezhetünk, ugyanis a 2012-es beszámolók egyike sem tartalmazott még ODR szolgáltató könyvtári feladatok ellátására fókuszáló információkat, míg, ha nem is teljes körben, de a 2017-es beszámolók egy része már tartalmazott ilyet. Ezzel együtt ezen esetben is megerősödik az a vélemény, hogy nem elegendő jogszabályban elöírni valamit. Módszertani támogatás nélkül a feladatok teljesítése esetlegessé és heterogénné válik.

\subsection{5. táblázat}

Az 1997. évi CXL. törvény hatása a beszámolók alapján

\begin{tabular}{|l|l|l|r|}
\hline \multirow{3}{*}{ 15. } & \multirow{2}{*}{ szakmai múhelynap } & Nincs említés a beszámolóban & 0 \\
& & Irreleváns említés található a beszámolóban & 0 \\
& & Releváns, de nem lényegi említés van a beszámolóban & 6 \\
& Releváns lényegi említés van a beszámolóban & 12 \\
\hline
\end{tabular}

A feladat a 66. \$-ban jelenik meg, ami a megyei könyvtár a megye egész területére vonatkozó feladatait sorolja fel. Ez a pont a kötelezően ellátandó alapfeladatok körét jelöli ki és kimondja, hogy a megyei könyvtár évente egy alkalommal a könyvtári szolgáltatások megvalósításával kapcsolatos információs szakmai műhelynapot szervez a megye könyvtárosai számára. Valamennyi beszámoló tartalmazta ezt az információt, azaz 100\%-os volt a releváns, lényegi említés, mégis hiányérzete van az elemzést végzőnek, hiszen a beszámolókból alig-alig derül ki további releváns és lényegi elem. Például, hogy teljesült-e a szakmai nap célja. Egyáltalán, mi volt a kitűzött 
cél? A cél teljesülését visszamérték-e? Mivel lehet igazolni az eredményességet? Az említési gyakoriság 2,25. Ez az érték nem tűnik kevésnek, bár ha a feltett kérdésekre is választ kaphattunk volna, akkor a „szakmai mühelynap” jelenléte a beszámolóban lényegesen rangosabb helyet foglalhatna el.

A 2012-es beszámolókban egyetlen említést sem regisztrálhattunk, azaz nyilvánvalónak tünik, hogy a jogszabály megjelenése és elöírása indukálta ezt a változást.

2.16. táblázat

Az 1997. évi CXL. törvény hatása a beszámolók alapján

\begin{tabular}{|l|l|l|r|}
\hline \multirow{3}{*}{ 16. } & \multirow{2}{*}{ társadalmi jólét } & Nincs említés a beszámolóban & 7 \\
& & Irreleváns említés található a beszámolóban & 0 \\
& & Releváns, de nem lényegi említés van a beszámolóban & 2 \\
& Releváns lényegi említés van a beszámolóban & 0 \\
\hline
\end{tabular}

A feladat a törvény céljainak meghatározása keretében, az 1-es $\$$-ban jelenik meg. Azaz egy átfogó feladatmeghatározásról van szó, amivel valljuk meg, nem tudtak mit kezdeni a könyvtárak. 2017-ben a legtöbb beszámoló egyszerüen nem is említi, így nem csoda, hogy az egy könyvtárra eső átlagos említések száma mindössze 0,25. Ha a 2012-es értékeket nézzük, akkor ott „0” értékkel szembesülünk. Az érdemi elmozduláshoz szükség lett volna erőforrásokra, elsősorban személyi feltételekre és módszertani támogatásra is.

\subsection{7. táblázat}

Az 1997. évi CXL. törvény hatása a beszámolók alapján

\begin{tabular}{|l|l|l|l|}
\hline \multirow{3}{*}{ 17. } & \multirow{2}{*}{ versenyképesség } & Nincs említés a beszámolóban & 8 \\
& & Irreleváns említés található a beszámolóban & 0 \\
& & Releváns, de nem lényegi említés van a beszámolóban & 0 \\
\cline { 3 - 3 } & Releváns lényegi említés van a beszámolóban & 0 \\
\hline
\end{tabular}

Az alapfeladatokat felsoroló 55. \$-ban jelent meg ez a pont, mellyel a könyvtárak úgy tünik nem tudtak foglalkozni. 2017-ben egyetlen beszámoló sem tesz említést róla. Meglepetés, hogy a 2012-es beszámolók esetében történt egy említés, ami 0,167 említési gyakoriságot eredményezett, ugyanis egy pályázat kapcsán szóba jött a versenyképességi szempont.

\section{Összegzés}

Mint az 1. ábra is mutatja, vannak olyan törvényi pontok, melyek esetében már a jogszabály módosítása előtt nagyobb figyelmet kapott az adott téma (azaz az alsó oszlop hosszabb, mint a felső). Elvileg ez nem lenne lehetséges, ennek ellenére öt esetben mégiscsak ez történt. 


\section{FEHÉr MikLós}

Vannak pontok, összesen hét esetben, ahol a törvényi módosítást követően az adott területre nagyobb figyelem irányult (a felső oszlop hosszabb), de nem túl nagy különbséggel.

És vannak pontok, ahol a törvény módosítása komoly változást generált a könyvtárak tevékenységében, illetve az erről szóló beszámoló hangsúlyaiban. Ez öt esetben történt meg:

1. könyvtárhasználók segítése,

2. KSZR működtetés,

3. megállapodás a kistelepülési önkormányzattal,

4. minőségirányítás a szolgáltatás szervezésben,

5. szakmai műhelynap.

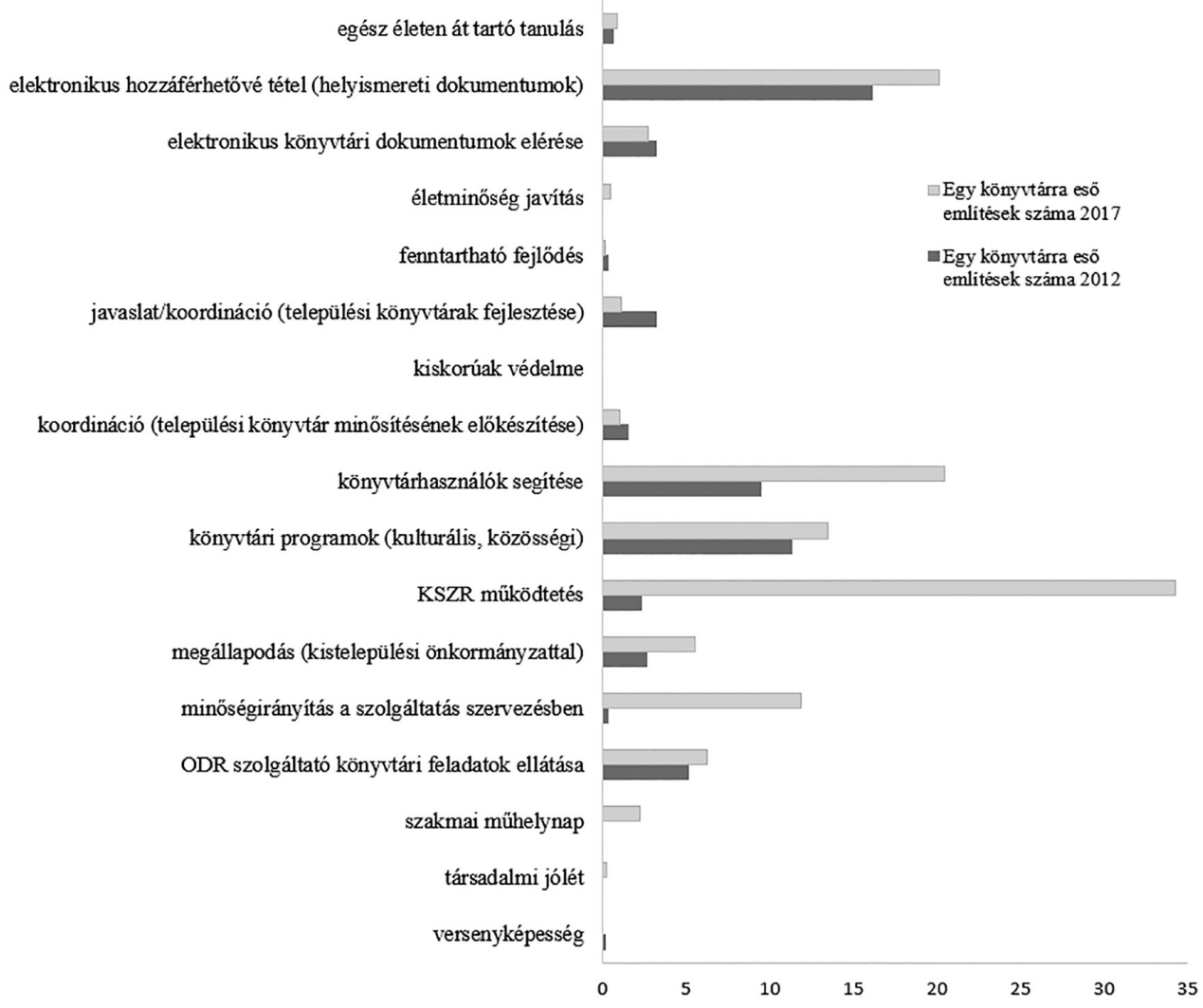

1. ábra

Az 1997. évi CXL. törvény új jogszabályi elemeinek átlagos említési száma a megyei könyvtári beszámolókban 2012-2017 közöttt

\footnotetext{
*Az ábrát a szerző készítette.
} 
Adódik a megállapítás, hogy azon pontok esetében lehet megfigyelni a markáns eredményeket, amelyeknél a jogszabály módosítás „nem maradt támasz nélkül”. Azaz, ahol kiemelt módszertani figyelem, együttmüködés, ellenőrzés történt. Ilyen támogatott és szakmailag erősen kontrollált szakterület volt a KSZR átfogó tevékenységrendszere, az ellátással összefüggő szakmai továbbképzés szervezése és a minőségügyi törekvések támogatása is.

Viszont, ha ez a megállapítás igaz, akkor ez azt is jelentheti, hogy bármi is jelenik meg jogszabályban, ez még önmagában nem elégséges ahhoz, hogy a rendszer müködésében egységes és markáns hatást fejtsen ki.

Ebböl következik, hogy a könyvtárügy szereplöinek, funkcióinak, beleértve a módszertani támogatást is együtt kell, sőt, inkább így fogalmazom: együtt lehet eredményes tevékenységet folytatniuk. A könyvtári rendszer üzemi müködését a szubszidiaritás elvét is betartva maguknak a könyvtáraknak, a könyvtárügy gyakorló szereplőinek célszerű moderálniuk. Az ágazati irányítás mérhetetlenül fontos szerepe e szint felett, a kulcsintézmények tevékenységének menedzselésében, képességeik magas szinten tartásában jelenik meg.

A hatékony ellátás érdekében a szakmai döntéseknek a könyvtárak által vezetett együttműködési körökben (hálózatokban) javasolt megszületniük, melyek számát érdemes lenne növelni. Figyelnünk célszerű az arányosságra is. De nem mechanikusan értelmezve azt. A települési könyvtári ellátás nagyságrendje a könyvtári rendszer egészén belül meghatározó, de ez nem jelentheti azt, hogy háttérbe szorulhat bármelyik, számosságában egyébként kisebb alrendszer müködése. Hiszen magunk valljuk:

- Nincs fontos vagy fontosabb könyvtár. Minden könyvtár a saját egyediségében páratlan és pótolhatatlan az adott földrajzi térben és tartalommal. (Amennyiben nem az, akkor meg kell szüntetni a redundanciát.)

- A könyvtári rendszer által alkotott szolgáltatási lánc pedig a mi esetünkben nem a leggyengébb láncszemnél szakad szét, hanem a legerősebbnél. Mert amit a legerősebb könyvtár tud, azt közvetítheti a gyengébb, de amit már ő sem tud, ott szakad a lánc.

Ezért mindnyájunk közös érdeke az erős könyvtár. Az erős, jól vezetett és együttműködésre kész könyvtár, és az ezt támogató, valamennyi szereplő által művelt közös könyvtári szakpolitika.

\section{Irodalom és jegyzetek}

1. 1997. évi CXL. törvény a muzeális intézményekről, a nyilvános könyvtári ellátásról és a közművelődésről

2. OSZK. Jogszabályok. Forrás: http://www.ki.oszk.hu/sites/default/files/dokumentumtar/ hatalyos_jogszabj_2019_0114.pdf [2019.július 6]

3. Lásd: 1997. évi CXL. törvény 63. \$. (4) 


\section{FEHÉr MikLós}

4. Az intézményi beszámolók a könyvtárak honlapjairól érhetők el, ott kerültek publikálásra. [2019. július 6.]

5. Az EMMI Könyvtári és Levéltári Főosztály által jóváhagyott megyei könyvtárak egységes beszámoló sablonjáról van szó.

6. 73/2003. (V. 28.) Korm. rendelet 4. \$.

Fehér Miklós a Könyvtári Intézet igazgatója. Egyetemi kiegészítő tanulmányait az ELTE BTK könyvtáros szakán végezte, ahol oktatója volt Barátné Hajdu Ágnes is. 1980-tól dolgozott, kezdetben pedagógus volt, majd 1986-tól könyvtáros a Balassi Bálint Nógrád Megyei Könyvtárban (Salgótarján). 1993-tól 1999-ig ugyanitt igazgató. Előbb a Fővárosi Szabó Ervin Könyvtár Központi Könyvtár igazgatójaként, majd 2001-től, a frissen alapított Könyvtári Intézet Szervezetfejlesztési és elemző osztálya vezetőjeként, munkatársaként tevékenykedik. Jelentősebb publikációi ebben az időben születtek. 2016-ban a Cselekvő közösségek projekt szakmai vezetője lett, majd 2017-ben megbízást kapott a Könyvtári Intézet vezetésére. A Magyar Könyvtárosok Egyesületének (MKE) 1987-től tagja. 2007-ben bekerült az MKE elnökségébe, melynek jelenleg is tagja. Egy ciklusban az MKE fötitkára. 2013-ban munkáját Szinnyei József-díj kitüntetéssel ismerték el. 